\title{
The Kraken: when myth encounters science
}

\section{O Kraken: quando mito e ciência se encontram}

\author{
Rodrigo B. Salvador \\ $\mathrm{PhD}$ student, Staatliches Museum für Naturkunde Stuttgart; \\ Mathematisch-Naturwissenschaftliche Fakultät/ \\ Eberhard Karls Universität Tübingen. \\ Rosenstein 1 \\ 70191 - Stuttgart - Baden-Württemberg - Germany \\ salvador.rodrigo.b@gmail.com
}

\section{Barbara M. Tomotani}

PhD student, Department of Animal Ecology/ Netherlands Institute of Ecology. Droevendaalsesteeg 10

6700AB - Wageningen - The Netherlands babi.mt@gmail.com

SALVADOR, Rodrigo B.; TOMOTANI, Barbara M. The Kraken: when myth encounters science. História, Ciências, Saúde - Manguinhos, Rio de Janeiro, v.21, n.3, jul.-set. 2014, p.971-994.

\section{Abstract}

Hundreds of years ago, sailors were terrified by the Kraken, a dreadful sea monster capable of sinking ships and with a taste for human flesh. Today we know the legends of this monster were based on sightings of giant squids. This animal belongs to the genus Architeuthis and was the subject of many scientific studies. Despite its enormous size (up to $18 \mathrm{~m}$ ), the giant squid is astoundingly elusive and much of its biology remains unknown. Thus shrouded in mystery, Architeuthis is almost a mythological creature and has a place both in science and in myth: the very last of the legends to persist to this day.

Keywords: Architeuthis; cephalopod; giant squid; Microcosmus marinus; sea serpent.

\section{Resumo}

Séculos atrás, marinheiros se amedrontavam com histórias do Kraken, um terrível monstro marinho capaz de afundar embarcações e devorar suas tripulações. Atualmente, sabemos que a lenda desse monstro foi baseada em encontros com lulas-gigantes. Esse animal pertence ao gênero Architeuthis e foi alvo de muitos estudos científicos. Apesar de seu enorme tamanho (pode chegar a $18 \mathrm{~m}$ ), a lula-gigante é incrivelmente elusiva e muito de sua biologia permanece desconhecida. Assim, envolto em mistério, Architeuthis é quase um ser mitológico, ocupando um lugar tanto na ciência como no mito: a última das lendas a persistir nos dias de hoje.

Palavras-chave: Architeuthis; cefalópode; lula-gigante; Microcosmus marinus; serpente marinha. 
The Kraken

Below the thunders of the upper deep;

Far, far beneath in the abysmal sea,

His ancient, dreamless, uninvaded sleep

The Kraken sleepeth: faintest sunlights flee

About his shadowy sides: above him swell

Huge sponges of millennial growth and height;

And far away into the sickly light,

From many a wondrous grot and secret cell

Unnumbered and enormous polypi

Winnow with giant arms the slumbering green.

There hath he lain for ages and will lie

Battening upon huge sea-worms in his sleep,

Until the latter fire shall heat the deep;

Then once by man and angels to be seen,

In roaring he shall rise and on the surface die.

(Alfred Lord Tennyson, 1830)

For the first navigators, the sea was a great unknown, treacherous, unstable, and above all, dangerous; yet, it was the only way to reach certain places. For these men, the sea seemed to hide in its inconceivable depths a horde of lurking monsters. Even the bravest seafarers showed a respectful dread of the sea, and the stories they told gradually became legends, for, as the saying goes, "the tale grows in the telling." An encounter with any unknown animal in the open sea had the potential to gain a mythological edge. For a monster worthy of its tales, gigantic size was not enough; it should also have some means to attack a ship and kill its crew.

Over the centuries, many sea monster legends were born and forgotten; only a few have reached our days. The Kraken, one of these "survivors," is perhaps the largest monster ever imagined by mankind. Its legend was also born from seamen's stories, but it was much modified and strengthened over the years. Right from the start, the Kraken was universally incorporated into Nordic mythology and folklore (Hamilton, 1839). According to an obscure, ancient manuscript of circa 1180 by King Sverre of Norway, the Kraken was just one of many sea monsters (Lee, 1883). Still, it had its own peculiarities: it was colossal in size, as large as an island, and capable of sinking ships; it haunted the seas between Norway and Iceland, and between Iceland and Greenland (Lee, 1883).

Two other Nordic sea monsters have records almost as old as the Kraken, appearing in the "Saga of Örvar-Oddr" (an Icelandic story from the thirteenth century by an anonymous author); their names are Hafgufa ("sea-mist") and Lyngbakr ("heather-back"). The habits of theses monsters were later described in the Norwegian encyclopedia Konungs Skuggsjá (from circa 1250, also by an anonymous author). They shared many features with the Kraken, namely their gigantic size (as big as an island or mountain) and their inclination to attack ships and their crews. Therefore, these monsters have been considered as references to the Kraken and are treated as the same monster.

However, nearly all sea monsters had some (or all) of these traits, and as such many of them were linked to or confused with (or, to borrow the lexicon of taxonomy, "placed in 
synonymy with") the Kraken over the centuries. Their features only reflected the fears of the first navigators, and the Kraken proved to be the strongest figure in their folklore, dragging every other sea monster under its shadow. The other monsters included the Aspidochelone (or Fastitocalon), a creature also similar to an island; possibly the bishop-fish (also known as the sea bishop, sea monk or monk-fish), a sea monster whose legend might also have originated from encounters with seals, sharks or walruses; and, finally, even the biblical Leviathan (Wallenberg, 1835; Ellis, 1998; Matthews, Matthews, 2005).

This confusion of creatures explains why the Kraken is found under so many guises in art and literature, from a misshapen mass to a giant cephalopod, passing through creatures as distinct as a humanoid sea giant, a huge, usually lobster-like, crustacean, and a sea serpent (Magnus, 1555; Gesner, 1587; Ashton, 1890). It was only much later that the Kraken's figure stabilized. Until the beginning of the eighteenth century, science and myth were not clearly separated, and the Kraken slowly but steadily took on the shape of a giant cephalopod, largely due to the increase in the number of sightings of giant squids as seafaring became more common. This culminated in the Kraken's "modern" form as a giant squid, which can be understood as a return to the animal that long ago originated the legend.

\section{The Kraken: scourge of the seas}

Before actually examining the science behind the monster, it is worth lingering a little more in the domain of mythology and further exploring the Kraken in all its legendary glory. First of all, it should be noted that although "Kraken" is the commonest name found in the literature, the monster answers to many other variants: Krake, Krabben, Kraxen, Skykraken and Crab-fish (Pontoppidan, 1752, 1752-1753; Wallenberg, 1835; Lee, 1883; Hamilton, 1839; Matthews, Matthews, 2005).

The Kraken's colossal size initially reached a few kilometers in length (Pontoppidan, 1752, 1752-1753; Wallenberg, 1835), but as the legend matured and took its molluscan shape, it was progressively diminished to more modest proportions. Of course, even this smaller Kraken was still large enough to attack and sink a ship (Figure 1), and its ability to do so is the commonest theme in its stories, reflecting sailors' fears. There are many accounts in the pseudoscientific and cryptozoological literature, and also in the official naval records, telling of encounters with the monster (e.g., Pontoppidan, 1752, 1752-1753; Hamilton, 1839; Ashton, 1890). They report that the Kraken would attack a ship with its strong arms, and if this strategy failed it could sink a vessel by creating a fierce maelstrom that could drag the ship to the bottom of the ocean. This is the most recurrent "ability" attributed to the Kraken in the literature, and it is found with some variations. Generally, it was thought that the Kraken would start swimming in circles around the ship (which clearly implies a much smaller size for the monster), thus creating the deadly vortex. However, when a larger size was attributed to the Kraken, the monster could create a maelstrom simply by submerging, and the helpless ship would be dragged down even if that was not the monster's original intent (Pontoppidan, 1752, 1752-1753).

Naturally, a monster would not be regarded as such if it did not have a certain taste for human flesh. Legends say that the Kraken was capable of eating a ship's entire crew; some 
even claim that the creature could devour the crew of an entire fleet at once. It is also worth mentioning the most curious piece of folklore about the Kraken: the belief that the amber (fossilized tree resin) found on the beaches of the North Sea was the monster's excrement (Matthews, Matthews, 2005).

Despite its fearsome reputation, the Kraken could also bring some benefits for people. Sailors believed that the monster swam accompanied by huge schools of fishes, telling how fishes cascaded down the Kraken's back when it emerged from the sea (Wallenberg, 1835). Some claimed that fishes ate the monster's excrement while others said that the Kraken produced some sort of "aroma" to attract its fish prey. Putting their fear aside, some fishermen risked going near the monster in order to secure a more bounteous catch.

Besides the myth, the Kraken was also immortalized in art, and two of its appearances deserve special attention. The first is the poem "The Kraken" by Alfred Lord Tennyson (1830), a sonnet where the author combines mythology (with strong references to the biblical Leviathan) and natural history (Thomson, 1986). The second, the novel Twenty thousand leagues under the sea by Jules Verne (1870), is better known (Figure 2): the monster, called simply "poulpe" (octopus) in the French original, attacks the crew of the Nautilus submarine (curiously, the name of another cephalopod).

\section{The monster tamed: the giant squid}

Curiously, even before the legend's birth, the real animal behind it was already known to Greek and Roman naturalists and had already been scientifically described (according to the manner of the day, of course). The Greek philosopher Aristotle (fourth century BC), in his work The history of animals, had already distinguished the common squid (teuthis) from its larger and rarer cousin (teuthus or, in some translations, teuthos), which could reach $2.3 \mathrm{~m}$ in length. Roman naturalist Pliny the Elder (first century AD), in his work Natural history, also described a giant squid, which had a body "as large as a barrel" and tentacles reaching $9.1 \mathrm{~m}$ in length.

Despite being known, the animal's rarity and extraordinary size were responsible for its later mythification. Still, both Aristotle and Pliny treated the giant squid as a common animal and did not link it to myths of their own age (and Greek and Roman myths were plenty!). However, some later authors (e.g. Tryon, 1879), especially in fictional literature, made this mistake (a "mistake" because the Kraken's legend originated from sailors' accounts dating from a millennium after the age of Pliny). In any case, this confusion is so recurrent that it is worth citing some of these Greco-Roman monsters here. The Kraken, already in its giant squid shape (sometimes even a giant octopus), was linked to some monsters of Greco-Roman mythology: (a) Scylla, the man-devouring she-monster from Homer's Odyssey, usually depicted as a beautiful woman from the waist up but with monstrous features below the waist, such as six dog's heads, twelve tentacles (although using the correct malacological terminology, those would be "arms") and a cat's tail; (b) Cetus, the monster to whom Princess Andromeda was sacrificed, generally depicted as a whale-like creature, as its name implies; (c) the Lernaean Hydra, the many-headed beast killed by Heracles; and (d) the nameless monster that blocked Straits of Gibraltar mentioned by Pliny. 


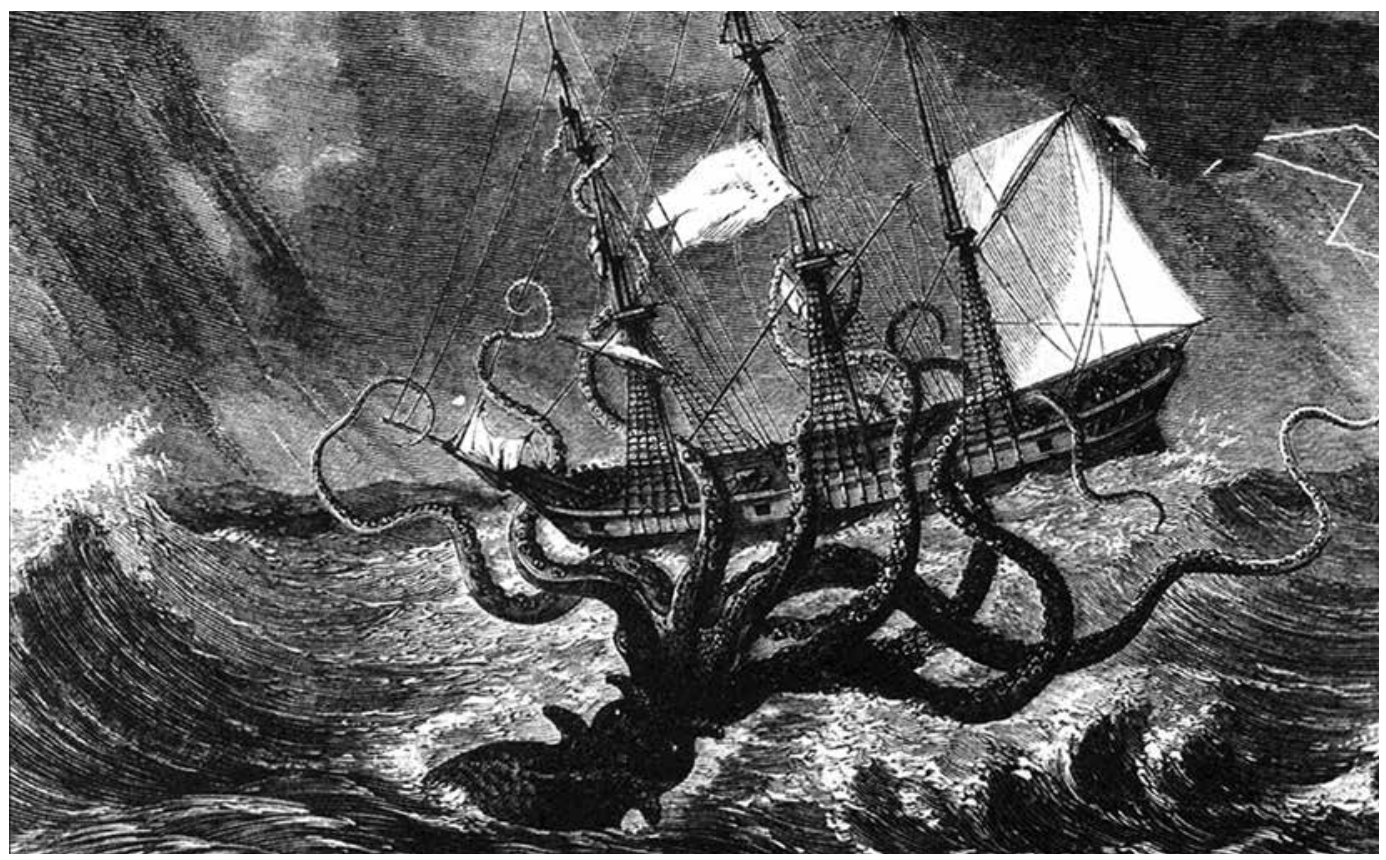

Figure 1: The Kraken, depicted with a more octopus-like appearance, attacking a ship (Author unknown. Available at: http://commons.wikimedia.org)
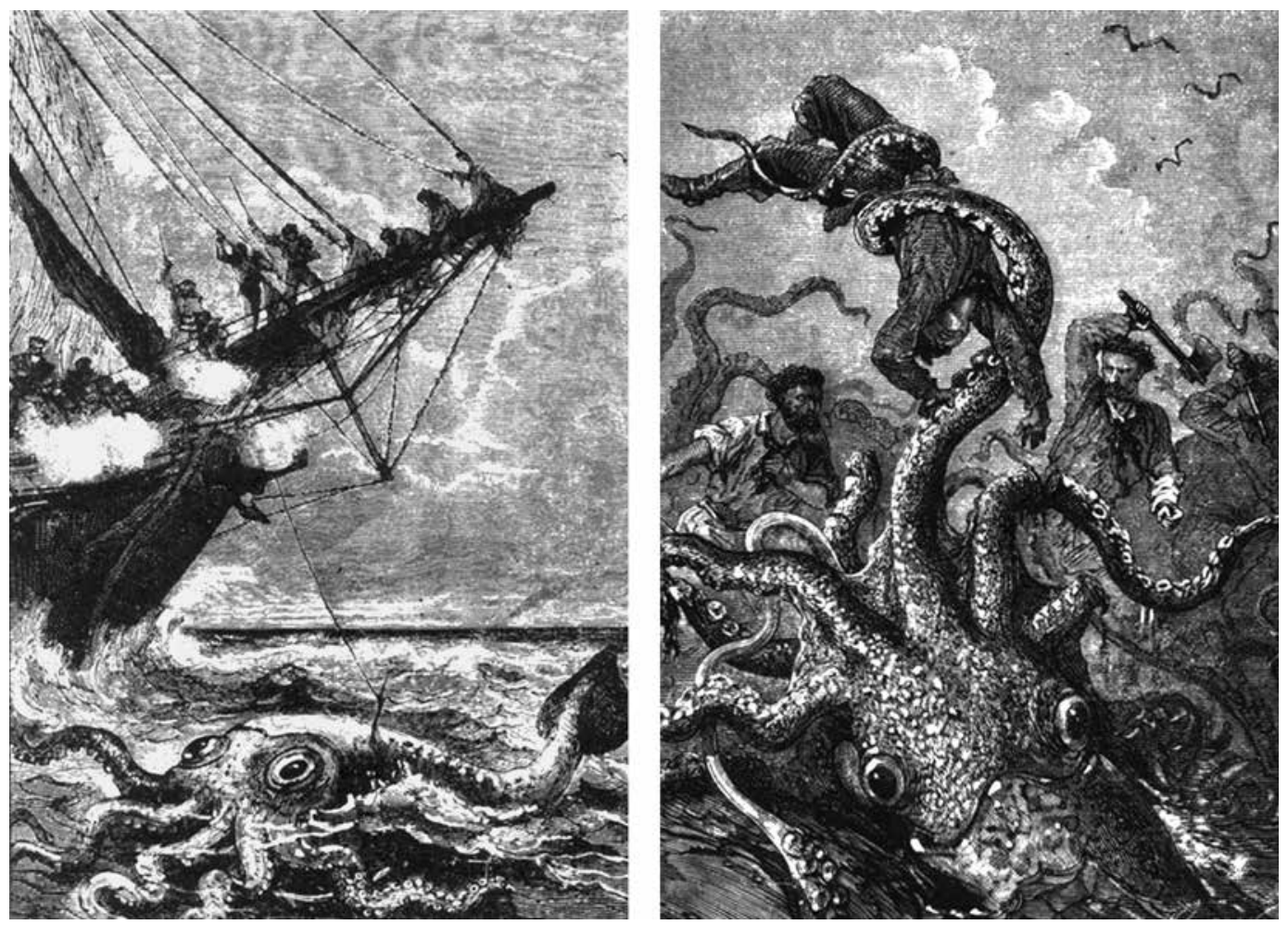

Figure 2: The original monster from Twenty thousand leagues under the sea. Despite its name, "poulpe", the monster more closely resembles a squid; the drawing on the right even shows a tentacle, a feature present only in squids (A. de Neuville and E. Riou [1870]. Available at: http://commons.wikimedia.org) 
After a long time away from the literature, the giant squid can be found again in the work of Olaus Magnus (1555), albeit indirectly: he presents descriptions of many monstrous "fishes," one of which seems to specifically refer to a giant squid (Ellis, 2004). Curiously, the giant squid per se is not present in Historiae animalium (1551-1587), Conrad Gesner's influential work. But that is not such a big surprise: Gesner only deals with marine animals in the last volume (from 1587), published more than 20 years after his death, and many believe that the author was not certain enough about the material to publish it. Nevertheless, the Kraken can still be found in Historiae animalium under another guise: a sea serpent described by Magnus some years earlier. (The reason for the confusion between the Kraken and sea serpents is explained below.)

Bishop Erik Pontoppidan describes the Kraken as the world's largest animal (a circumference of $2.5 \mathrm{~km}$ ) in his work, The natural history of Norway (1752; 1752-1753). The book's name gives the idea of something more scientifically oriented, but it is actually closer to mythology. The bishop reports that the Kraken, when rising from the sea, could easily be mistaken for a mountain; its colossal size made it more similar to an island than to an organized being. To give an idea of the creature's size, Pontoppidan tells that an entire regiment of soldiers could practice their battle maneuvers on the Kraken's emerged back. He also claims that the reports of "floating islands," common in those days, were actually nothing more than encounters with the Kraken. Pontoppidan also tells the story of the Bishop of Nidros, who confused the sleeping Kraken with an island: the man and his crew landed on the monster's back to celebrate a mass and only realized their mistake when the creature woke up.

Pontoppidan's reports were discredited by almost all later naturalists due to his exaggerations and plain inventions (see, chiefly, Tryon, 1879). However, some authors still defended Pontoppidan much later (e.g. Hamilton, 1839; Ashton, 1890). Hamilton (1839) is a special case because he oscillated so much between science and myth: despite alluding to the possibility of the Kraken being a giant cephalopod, he still gave much credit to the "monster stories." Pontoppidan had already reported the monster's habit of blackening the sea with a gush of dark liquid. This was not taken into account later, which is very curious, because this ability could easily have been linked to the cephalopods' behavior of expelling ink (see below). Moreover, Wallenberg (1835) claimed that the monster expelled water by its nostrils, another behavior commonly found in cephalopods, which use jet propulsion as a mean of quick locomotion. It is also interesting to notice that Hamilton (1839) observes that sailors from many cultures (including places as distant as China and Japan; see also Ashton, 1890) had developed similar monsters in their folklore, and calls attention to the fact that a single real animal gave birth to all these legends.

The Kraken was so strong an influence in Nordic folklore that most naturalists could not escape its allure. Not even Linnaeus (1735), the father of taxonomy and one of the most prominent figures in the history of biology, could avoid it: he included the Kraken in the first edition of his Systema naturae, where he classified all known organisms. The name he chose was Microcosmus marinus, later understood as Sepia microcosmos. (Curiously, the cuttlefish, another kind of cephalopod, was and still is classified under the genus Sepia, and the Kraken itself was deemed a cuttlefish on some occasions.) In another work, Fauna Svecica, Linnaeus (1746) also used the classification Microcosmus marinus for the Kraken, stating that it was a 
"singular monster" that inhabited the Norwegian seas, despite claiming that he had never personally seen it. However, Linnaeus later regretted describing an imaginary beast in his scientific works and removed the Kraken from further editions of Systema naturae (reprint in 1756). In any case, after this event, everyone (naturalists or not) adopted once and for all the image of a giant squid for the Kraken; i.e. Linnaeus's "formal" description of the Kraken marked the point when the mysterious monster took on its modern cephalopod form (Tryon, 1879).

The oldest certified record of a giant squid (rediscovered by Norwegian naturalist Japetus Steenstrup in 1849), besides Aristotle's and Pliny's, seems to be a carcass found in Thingøre Sand, Iceland, in 1639. At approximately the same time, whalers began to realize that the sperm whales they hunted regurgitated fragments of huge arms when killed, and the sailors did not take long to relate these pieces to the Kraken (Nordhoff, 1856; Ellis, 2004). In December 1853, a giant cephalopod was found stranded on Raabjerg beach, Denmark, but was completely cut into pieces for bait. The only part recovered from this animal was its beak, used by Steenstrup (1857) to describe the species Architeuthis monachus. Still in 1857, Steenstrup seemed to use another name (Architeuthis $d u x$ ) for the same animal, creating a taxonomic problem that would only be solved many years later (see below). This was the point at which the Kraken officially and permanently entered the annals of science. Nevertheless, perhaps the most famous record of a giant squid is that of the French vessel Alecton, whose crew, on 30 November 1861, harpooned a squid of about $7.5 \mathrm{~m}$ in length close to Tenerife, Canary Islands (Figure 3). However, when the crew tried to drag the animal on board, its body broke up and they only managed to retrieve the top of the mantle (Ellis, 2004).

The next place where giant squids appeared was Newfoundland Island, Canada, with the discovery of many specimens from 1871 onwards. Of the first animals found, nothing remained, but two fishermen recovered a piece of a tentacle from an animal that supposedly had attacked them (Ellis, 2004). The men took the tentacle fragment to Reverend Moses Harvey, an amateur naturalist (Aldrich, 1991; Ellis, 2004). As the only thing remaining of Steenstrup's specimens was a beak, this was the first conclusive vestige of a giant squid. Later, in 1873, Harvey managed to secure a complete specimen that was still alive the moment it was captured; this resulted in one of the most celebrated photos in the history of Architeuthis studies (Figure 4). Harvey was an amateur, but knew of the great value that his specimens had to science and called on the assistance of professional malacologist Addison E. Verrill. Until 1881 , about 60 specimens were stranded on the beaches of Newfoundland, supposedly due to a change in the ocean's currents (Ellis, 2004), and Verrill was the one who took responsibility for studying those that were not destroyed by fishermen. Based on that first tentacle fragment, Verrill (1875) described the species Architeuthis princeps (Figure 5).

Verrill's many works (e.g. 1874; 1875; 1879-1880), besides continuing the line of Steenstrup and establishing a strictly scientific study of giant squids, reintroduced the genus Architeuthis and its species to the scientific literature. Verrill identified the first specimens as $A$. monachus, but they were later classified as $A$. dux. The reason for this lies in one of the rules of taxonomy: since the original mention of $A$. monachus by Steenstrup (1857) did not have a proper taxonomic treatment - it was not accompanied by a formal description and a figure - this name was considered a "nomen nudum" (Robson, 1933), a term indicating that the name A. monachus must not be accepted or used by the scientific community. As such, 


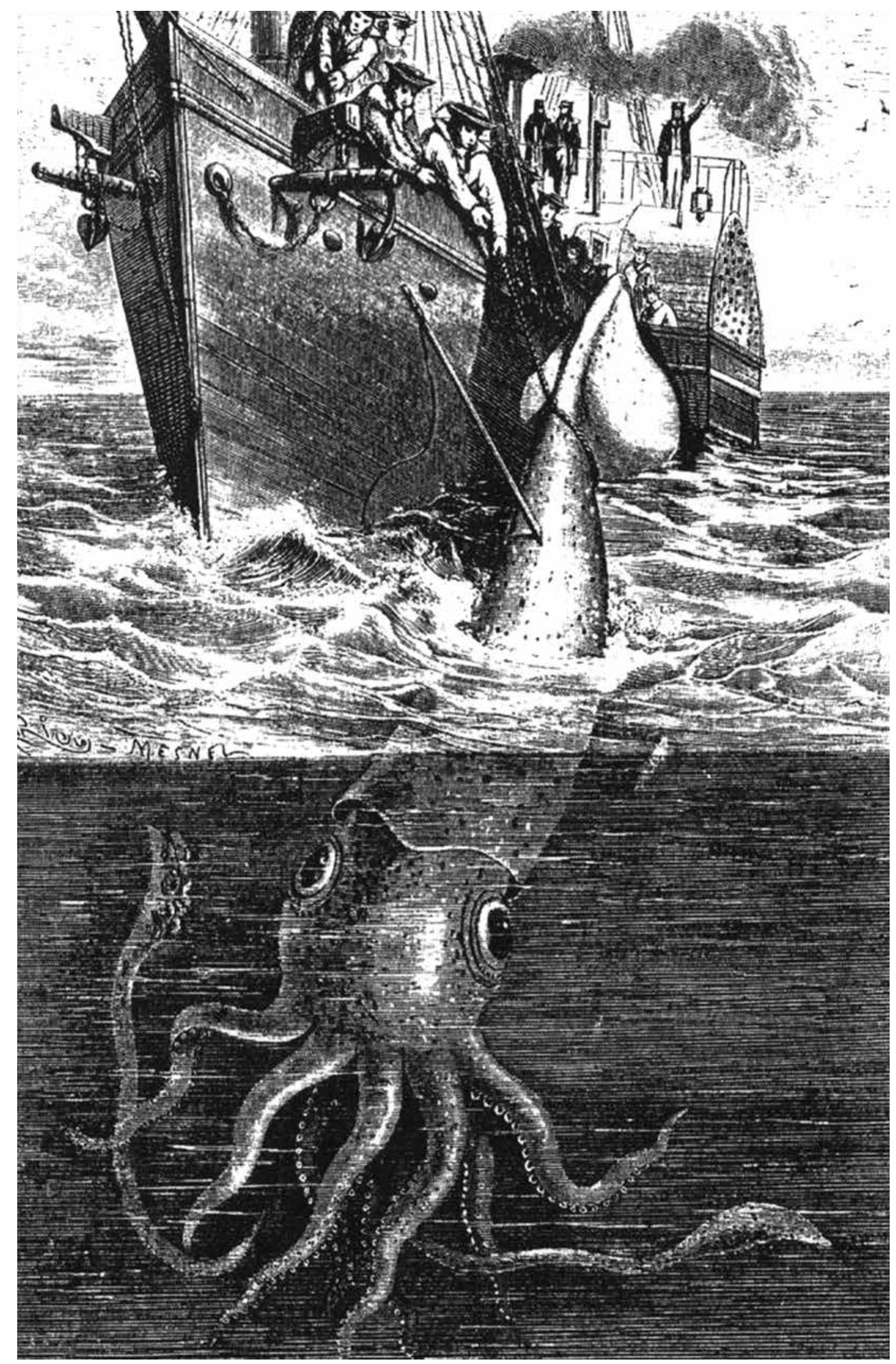

Figure 3: The crew of the Alecton try to bring the captured squid on board (Author unknown. Available at: http:// commons.wikimedia.org) 
the official name for the species became $A$. $d u x$, the name given by Steenstrup (1857) to the same animal. At the same time that the specimens appeared in Newfoundland, many others were found in New Zealand, Norway (Figure 6) and other places, transforming the study of giant squids into a worldwide enterprise.

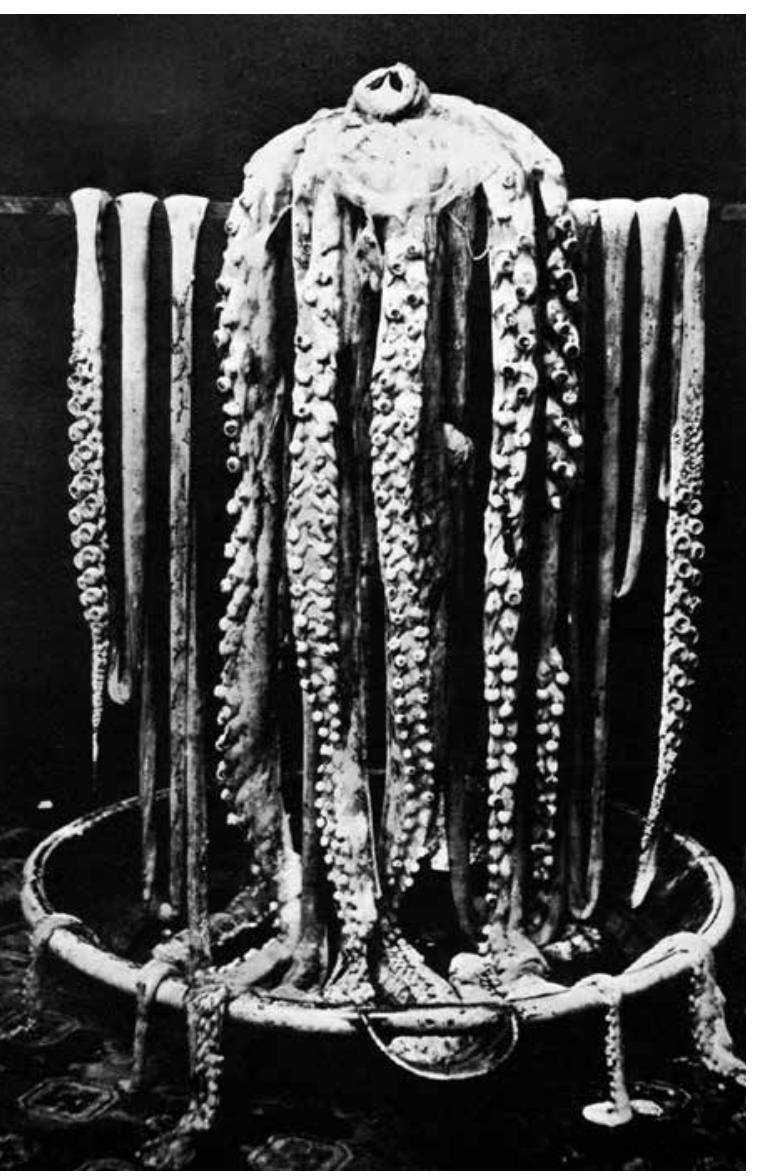

Figure 4: Harvey's photo of the squid on his sponge bath is the best known image of Architeuthis (M. Harvey [1873]. Available at: http://commons.wikimedia.org)

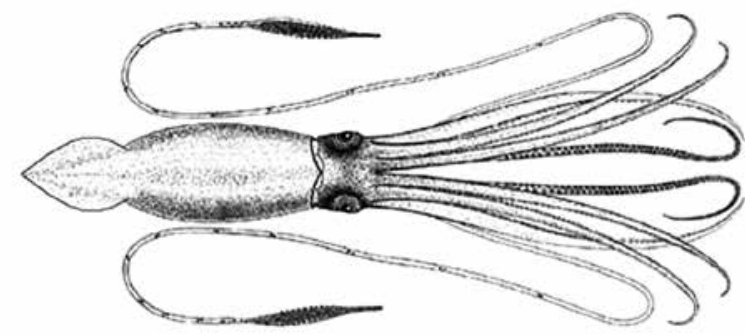

Figure 5: Illustration of $A$. princeps (A. E. Verrill [1879-1880]. Available at: http://commons. wikimedia.org)
Tryon (1879) reserved a curious entry for the Kraken in the first volume of his Manual of conchology, a series that would deal with all mollusks. Worried about the excess of imagination that haunted the study of giant cephalopods, he made an extra effort to demystify all sea monsters, especially the absurdities of Pontoppidan and Pierre Dénys de Montfort (the latter was an account of a supposed giant octopus, unrelated to the Kraken). At the time, many reports began to appear and the identity of such monsters was fiercely debated, even attracting the attention of great names in natural history like Richard Owen, William Dall and Alcide d'Orbigny; however, few were the specimens collected and available for study. Besides, such reports seemed to indicate that the Kraken also lurked in the Pacific Ocean, in waters very distant from its Nordic home. Therefore, Tryon revised all references to these creatures in the literature, attributing them to known species, either in the genus Architeuthis or in other genera (including some octopuses). Tryon acknowledged the genus Architeuthis as a separate entity from other squids, but preferred to treat it as a subgenus of the genus Ommastrephea. He also acknowledged Steenstrup and Verrill's species, adding them to the body of global scientific knowledge. Manual of conchology was for a long time the greatest authority in molluscan studies, and it remains so for some groups even to this day.

\section{Squid or octopus?}

Besides the initial confusion of shapes mentioned above (squid, octopus, sea serpent, crustacean etc.), the Kraken was commonly confused with an octopus even after its image was linked to the giant squid. Such confusion was not only present in art and fiction, but also in the popular knowledge of the real animals, i.e. the Kraken's "smaller cousins." This confusion, already reported by Lee (1883), 


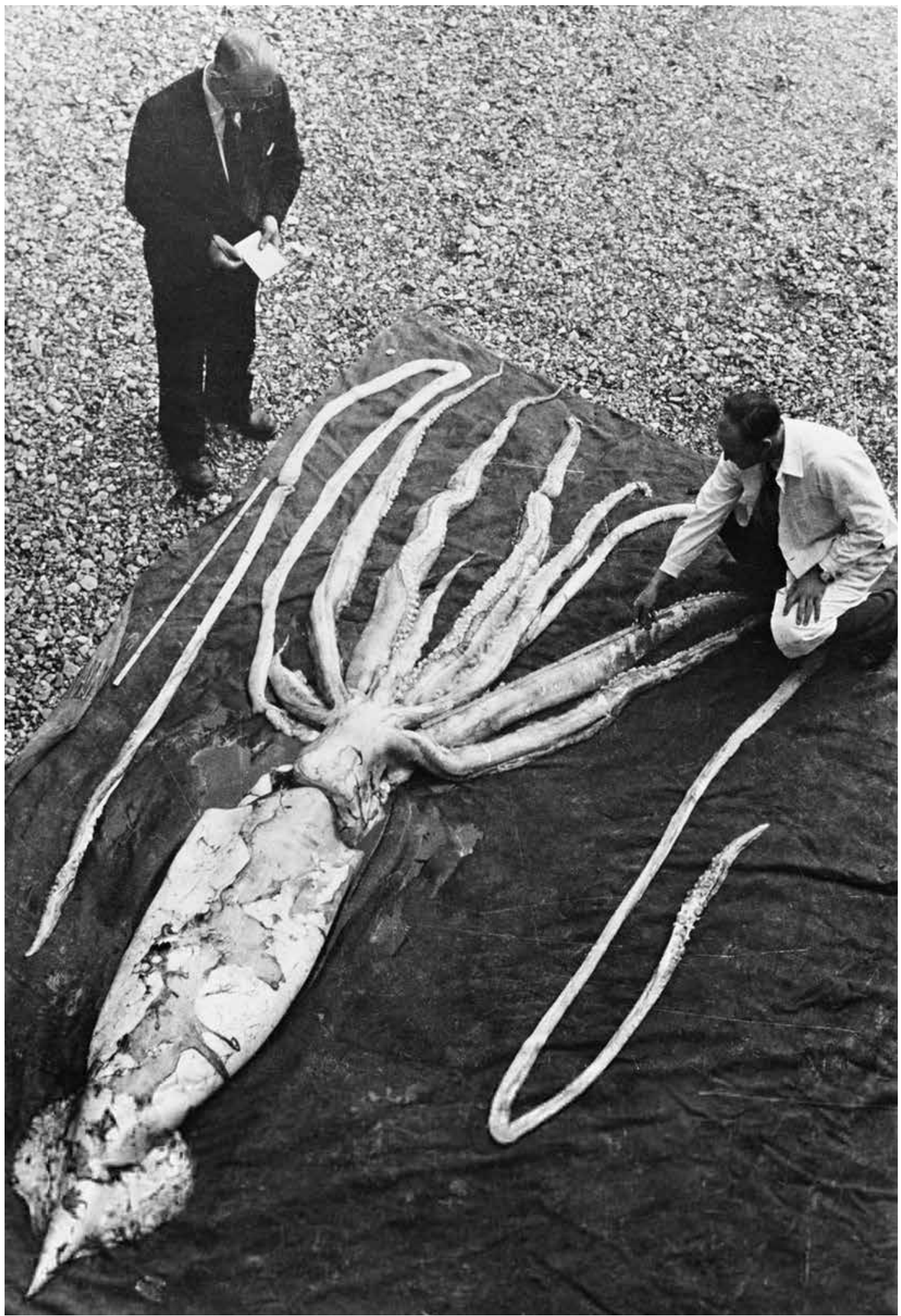

Figure 6: Photo of an Architeuthis specimen found in Ranheim, Norway, being measured by Professors Erling Sivertsen and Svein Haftorn (NTNU Museum of Natural History and Archaeology [1954]. Available at: http://commons. wikimedia.org) 
unfortunately persists to this day. But, after all, what is the difference between an octopus and a squid?

Both are mollusks and belong to the class Cephalopoda, together with cuttlefish, nautiluses, and fossil belemnites and ammonites. Maybe the most striking feature of mollusks is their marvelous shells. However, contrary to the rest of the phylum, most living cephalopods do not have shells (nautiluses being the exception). Squids only have a remnant of a shell called a "pen" (or gladius, to use the scientific term), a mineralized chitinous structure lodged inside the mantle that works as a skeletal support for the body. Octopuses have completely lost their shells during their evolutionary history.

At first sight, squids and octopuses may look rather similar in their overall shape, but squids generally have a more bullet-like shape and hydrodynamic body, with a pair of fins on their extremity, while octopuses have a more globose body that can greatly change in shape (Figure 7). This is due to their way of life: squids are active swimmers, while octopuses live on the sea floor and hide under rocks or in burrows (they also have the greatest camouflage ability in the animal kingdom), although there are some exceptions, such as paper nautiluses (Argonauta spp.). However, the most striking difference lies somewhere else: while an octopus has only eight arms, a squid has eight arms and two tentacles, which can be readily identified, for they
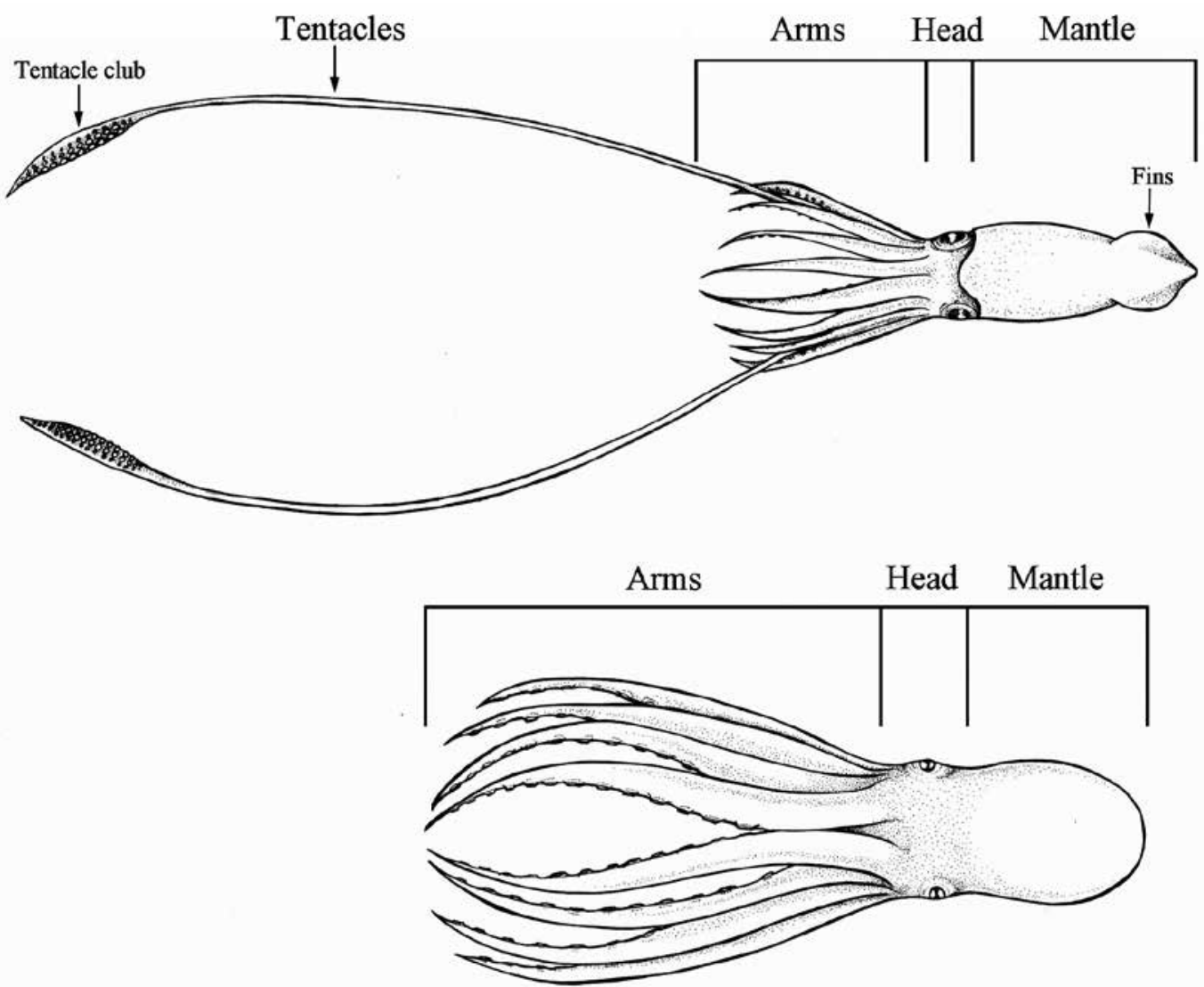

Figure 7: Diagrams of a squid, in this case Architeuthis (above), and an octopus (below), accompanied by the proper scientific terminology (B. M. Tomotani) 
are more slender and usually much longer than the arms. The difference in meaning between "arm" and "tentacle" is crucial, but has been consistently overlooked in the popularization of science (not to mention fiction!), where these words are used interchangeably. The arms of both octopus and squid are covered on their inner surface by suction cups (or suckers), but those of an octopus are sessile while squids have stalked mobile cups. Squids' tentacles are smooth (i.e. without cups) along almost their whole length, but the tip of the tentacle, called the club, bears some cups.

In all other respects, squids and octopuses are very similar, but there are still some features of general cephalopod anatomy and ecology that are worth mentioning. Their mouth is located in the middle of the circle formed by the arms and contains a pair of powerful chitinous mandibles called a "beak" due to their resemblance to a parrot's beak. Beaks are often cited in taxonomy, as a genus and sometimes even a species can be identified by its beak alone (Ogden et al., 1998; Roeleveld, 2000). Inside the mouth lies the radula, a rasping tongueshaped structure equipped with many rows of small chitinous teeth, giving it the capacity to pluck small portions of food. The radula is a feature common to all mollusks except bivalves, which are filter feeders and have lost the radula in the course of their evolution.

Cephalopods breathe through gills located inside the mantle cavity: water enters this cavity through apertures on the mantle edge close to the head, bringing oxygen to the gills, and is expelled by a structure called funnel. The funnel is also capable of expelling a powerful gush of water, responsible for the fast jet-propulsion movement of cephalopods. An ink sac can also be found inside the mantle cavity, which enables the animal to expel a dark cloud of ink through the funnel to disorient a predator and escape. Cephalopods have specialized cells in their skin called cromatophores, which enable them to instantly change color and camouflage themselves (either to escape predators or to ambush prey) or to communicate with conspecifics. Finally, cephalopods have a complex nervous system, and are highly intelligent.

\section{Sea serpents: reptiles or mollusks?}

Other terrible monsters that lurked in the sea and terrorized sailors were sea serpents, reptile-like (sometimes even dragon-like) beasts capable of sinking ships and devouring their crew. There are countless seamen's reports about encounters with sea serpents, both in official naval records and in the scientific and cryptozoological literature (see, chiefly, Magnus, 1555; Gesner, 1587; Ashton, 1890). Ellis (2004), like Lee (1883) a century before, presents a list of such reports and concludes that the vast majority of them could be reduced to encounters with giant squids (the rest being eels and other fish). According to these authors, the description of such sea serpents commonly includes: (1) an elongated and sinuous serpentiform body (squids swim with their arms and tentacles held close together and can give the impression of being a serpent); (2) an eyeless and mouthless head (the sailors may only have seen the club of a tentacle or the tip of the mantle above the water level; Figure 8); (3) a water gush that the serpent expelled from its mouth (squids usually use such water jets, expelled through the funnel, to escape and, in this case, to ward off harassing fishermen; Figure 9). As such, when more closely examined, another common legendary creature, the sea serpent, also becomes a giant squid or, more specifically, Architeuthis. 

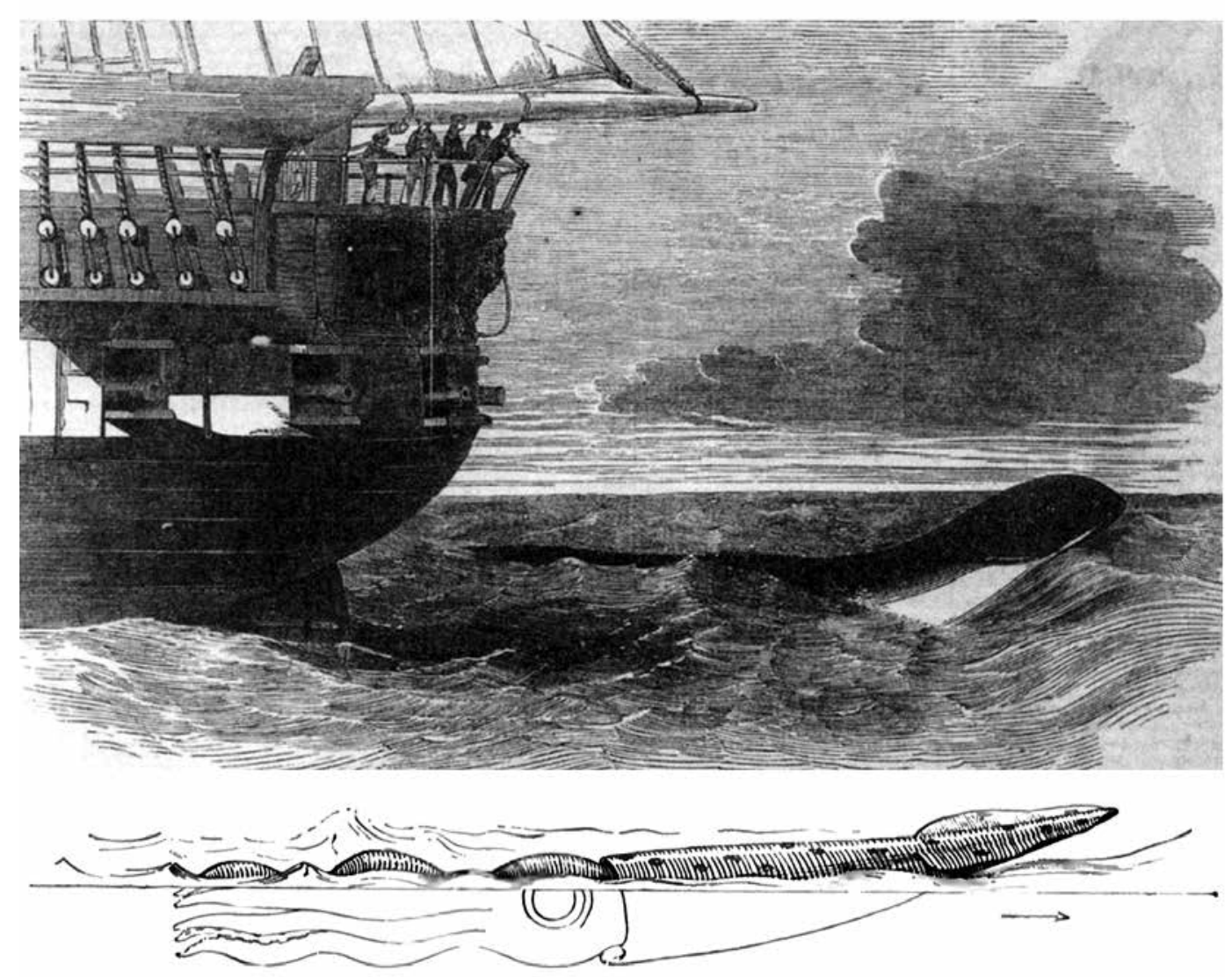

Figure 8: (Above) supposed sea serpent sighted by the crew of the Daedalus in 1848 near the Cape of Good Hope. Note the absence of eyes and how it is simpler to interpret the monster as the tip of a giant squid's mantle (Author unknown. Available at: http://commons.wikimedia.org); (below) the scene most likely witnessed by the crew of the Daedalus (H. Lee [1883])

\section{Architeuthis, wanted dead or alive}

As seen above, all Architeuthis specimens recovered until the beginning of the twentieth century were almost exclusively stranded on beaches. Subsequent marine research began using new methods to capture animals, including trawling nets, but few were the giant squids captured at sea. This even led some authors (Roper, Boss, 1982) to question whether squids were able to avoid capture somehow. In any case, all the recovered animals were dying or already dead (and in a bad state of preservation); in the worst cases, only parts of the animal, like a tentacle fragment, were recovered. The difficulty in finding specimens is reported by Aldrich (1991), who started distributing posters saying, "Wanted! Dead or alive", and even offering rewards. (He says he managed to secure many specimens this way.)

Even so, a large number of records were gathered, giving a good idea of the geographical distribution of Architeuthis (see Ellis, 2004, for an exhaustive list of all animals sighted and/ or recovered). With all these data, it is clear that Architeuthis is a cosmopolitan genus, i.e. it occurs in the entire world, but it is especially abundant in the North Atlantic, the western North Pacific and off the South African and New Zealand coasts (Robison, 1989; Aldrich, 1991; 

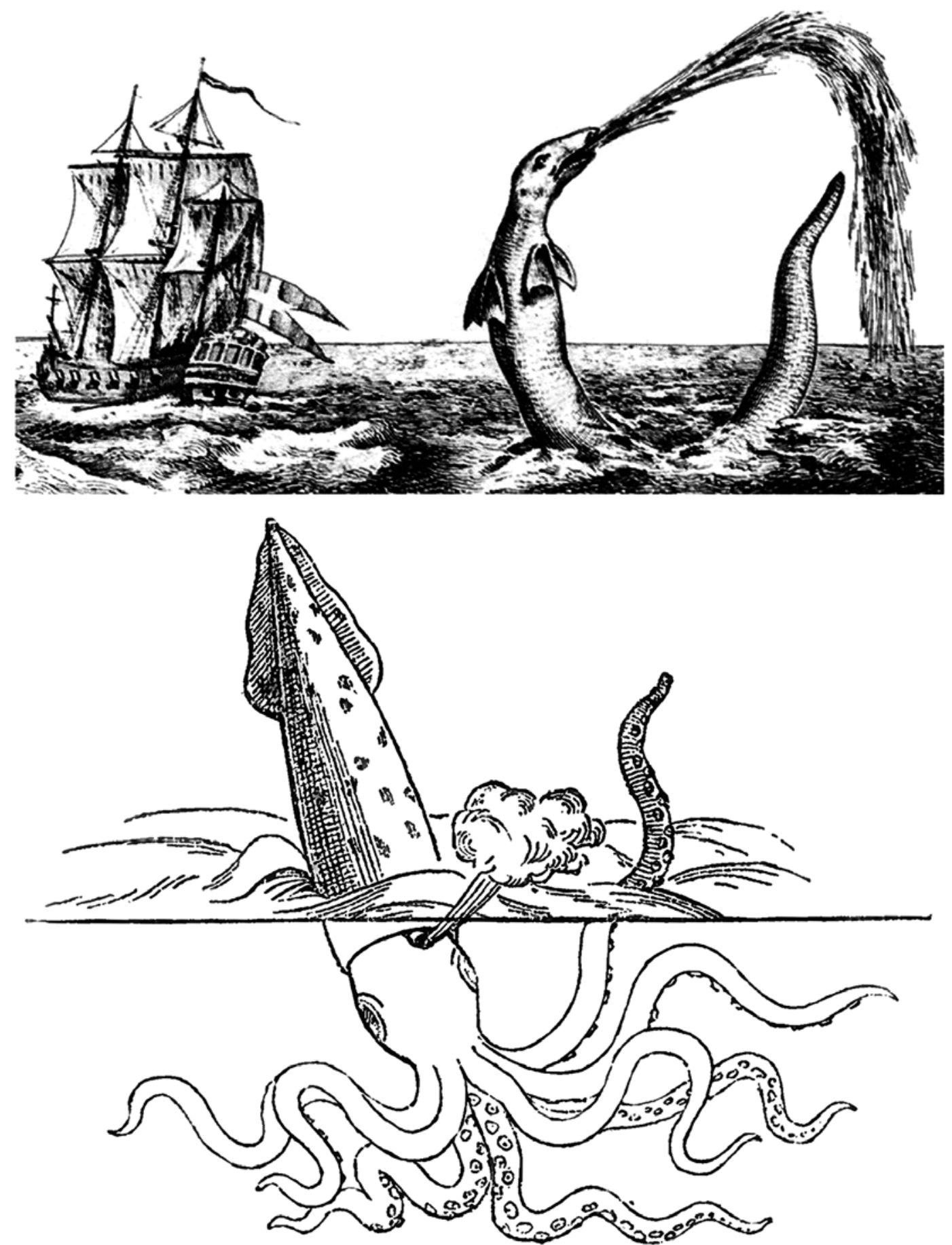

Figure 9: (Above) sea serpent squirting water from its mouth, as reported by Bishop Hans Edge of Greenland in 1734. Artistic exaggerations aside, a gush of water from a squid could easily be seen above the water level (Author unknown. Available at: http://commons.wikimedia.org); (below) the scene most likely witnessed by Edge (H. Lee [1883]) 
González et al., 2000). Some authors (Roper, Young, 1972; Nesis et al., 1985) suggested that Architeuthis reproduced in warm waters, where the juvenile would grow, and then the adults would migrate to temperate or cold waters, where they would feed, grow and mature. However, this hypothesis was disproved when additional data surfaced: Roeleveld \& Lipinski (1991) showed that Architeuthis live and reproduce in the same area.

Architeuthis, the single genus of the family Architeuthidae, has about 20 species, many precariously described, usually based only on tentacle fragments (Figure 10), beaks (Figure 11) or other body parts (Clarke, 1966, 1968; Roper, Boss, 1982; Roeleveld, 2000). Until the 1940s, it was common practice to describe a new species whenever a new fragment was

Figure 10: The tip of a tentacle, also known as the club, of Architeuthis. The four rows of suction cups are an exclusive feature of the genus (Roper, Boss, 1982; Aldrich, 1991) (A. E. Verrill [1879]. Available at: http:// commons.wikimedia.org) found, as Steenstrup, Verrill and others had done. This is why the descriptions were never accompanied by clear diagnoses to distinguish among the many species (Clarke, 1966; Roper, Boss, 1982; Roeleveld, 2000). Thus, the family's taxonomy remains messy to this day, in large part due to the scarcity of well-preserved material and the logistical difficulty of conducting a comparative study with such huge animals. Moreover, the existing material is scattered throughout many museums and universities in different parts of the world, and a good portion of the original specimens were discarded, since the institutions are hardly equipped to house more than one of these monsters (Aldrich, 1991). This confusion has led many researchers to avoid identifying the species in their works, referring to the object of their studies simply as Architeuthis sp. or even only Architeuthis.

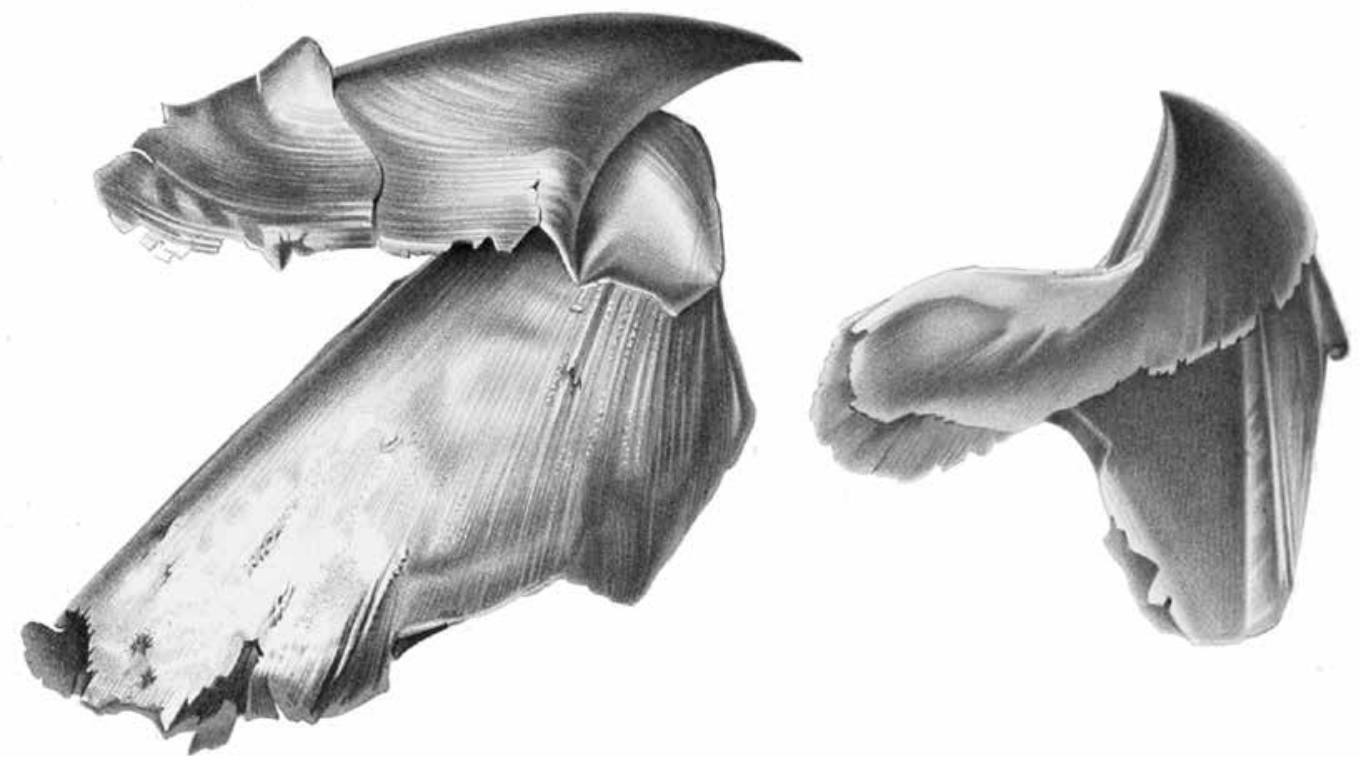

Figure 11: Beak of the Architeuthis (L. Joubin [1900]. Available at: http://commons.wikimedia.org) 
Therefore, it can easily be seen that the genus is in dire need of a taxonomic revision, especially when taking into account the large number of specimens recovered since the species' original descriptions. A handful of authors have risked issuing some opinions regarding the group's taxonomy, but none have conducted any proper revisionary work. Some believe that few of the current species are valid: for Roper and Boss (1982), for instance, the genus only has three valid species: A. dux from the North Atlantic, A. japonica from the North Pacific, and A. sanctipauli from the southern hemisphere. Others (Aldrich, 1991; Förch, 1998; Roeleveld, 2000) claim that all the genus diversity can be accommodated in a single species of variable morphology, namely $A$. dux. However, the division into a few species seems better grounded, for some striking differences have been described between the animals from the Pacific and from the Atlantic, as well as between the two "populations" from the North Atlantic (Roper, Young, 1972). Besides, there is still the curious case of the "dwarf" Architeuthis, a giant squid that reaches maturity with an astoundingly small size, less than $30 \mathrm{~cm}$ (Toll, Hess, 1981). It is very likely a new species and, according to Roeleveld and Lipinski (1991), also deserves a separate genus to accommodate it (albeit still in the family Architeuthidae).

\section{The biology of the elusive Architeuthis}

Little is known about the biology of giant squids. Since almost all the available specimens for study have been found dead or dying, little information could be extracted from them (Roper, Sweeney, Nauen, 1984). Even so, malacologists have made every effort to extract as much as they could from their specimens. Therefore, knowledge has advanced slowly (and is permeated by speculations), depending largely on the luck of finding good specimens to work with. Still, a great deal of information has been gathered in this century and a half of studies.

The coloring of Architeuthis goes from dark red to brown, but it very likely shares with other squids the ability to instantly change color (Roper, Boss, 1982; Aldrich, 1991). The giant squid's eyes are the largest in the animal kingdom, but are proportionally small when compared with other cephalopods (Roeleveld, Lipinski, 1991). Cephalopod eyes tend to be as complex as those of birds and mammals, and since vision is their main sense, the large eyes of Architeuthis most likely serve some purpose in the dark depths it inhabits. The importance of its ability to change color at such depth and the function of its eyes in locating prey and ink in escaping from predators (its ink sac is relatively small) remain elusive (Ellis, 2004).

Like some other squid species (such as the families Enoploteuthidae, Histioteuthidae and Bathyteuthidae), Architeuthis has pockets in its muscles containing a solution of ammonium ions $\left(\mathrm{NH}_{4}^{+}\right)$, which is less dense than seawater (Clarke, Denton, Gilpin-Brown, 1979; Boyle, 1986; Robison, 1989). This solution grants the giant squid neutral buoyancy, i.e. it can keep itself steady without having to continually expend energy swimming (Roper, Boss, 1982). This feature was first thought to had evolved only once in the squids' history and that all the families belonged to the same lineage (Roeleveld, Lipinski, 1991), but this hypothesis has recently been questioned (Voight, Pörtner, O'Dor, 1994). Besides, when some other morphological and anatomical features are taken into account, the family Architeuthidae seems to be a relatively ancient lineage among squids (Roeleveld, Lipinski, 1991). 
Robson (1933) was the first researcher that tried to discover something about the giant squid's way of life through its anatomical structure. This was the beginning of a heated debate in the scientific literature about the capabilities of Architeuthis. Some authors defend the idea of an agile, powerful predator worthy of the erstwhile myths. For them, the animal's powerful musculature, mainly in its funnel and mouth, as well as the high levels of enzymatic activity and protein concentration in the muscles indicate a good swimmer, apt for capturing active prey (Clarke, 1966; O'Dor, 1988; Robison, 1989; Aldrich, 1991; Seibel, Thuesen, Childress, 2000). On the contrary, there are some studies indicating that it has a limited oxygen transport capacity in the blood (Brix, 1983, but his results have been fiercely contested by Boyle, 1986) and weak muscles in the fins and funnel (Robson, 1933; Roper, Boss, 1982), with a small concentration of proteins, lipids, cholesterol and glycogen (Rosa, Pereira, Nunes, 2005). This has led some authors to consider the giant squid a slow and relatively weak animal, preying by ambush with its long tentacles (Robson, 1933; Roper, Boss, 1982; Pérez-Gándaras, Guerra, 1989; Roeleveld, Lipinski, 1991).

Aldrich (1991) claimed that those who considered Architeuthis a weak swimmer confused speed with agility and maneuverability. Therefore, the giant squid would have low maneuverability and agility, but would be a potent swimmer, capable of reaching great speeds; at least fast enough to escape its main predator, the sperm whale (Physeter macrocephalus). Aldrich (1991) cites Grønningsæter (1946), who sighted a giant squid swimming on the sea surface and calculated its speed at 20 to 25 knots ( 37 to $46 \mathrm{~km} / \mathrm{h}$ ); nevertheless, this record remains doubtful (Ellis, 2004). In any case, the giant squid's cruising speed, its most used kind of movement, would not require such powerful muscles as expected by some authors, since it uses very little of the cephalopods' muscular capability (Ellis, 2004).

The stomach contents of an animal can be used to discover its diet and therefore infer its feeding strategy (and, indirectly, ascertain whether Architeuthis is indeed a powerful predator). Despite the fact that a squid's beak and radula turns almost all food into unrecognizable bits (the Architeuthis beak reaches up to $15 \mathrm{~cm}$ and the radula $10 \mathrm{~cm}$; Roper, Boss, 1982), some information can sometimes be extracted from its stomach contents. Architeuthis feed mainly on fishes and squids, and many prey species have been identified (Roper, Young, 1972; Pérez-Gándaras, Guerra, 1978, 1989; Toll, Hess, 1981; Förch, 1998; Lordan, Collins, Perales-Raya, 1998; Bolstad, O'Shea, 2004). Crustaceans, bivalves and other benthic animals, as well as algae, have sporadically been found (Aldrich, 1991; Förch, 1998; Lordan, Collins, Perales-Raya, 1998), but are either considered secondary ingestion (i.e. they would have been previously ingested by the prey) or are present only in stranded Architeuthis specimens and are therefore not considered natural components of its diet (Bolstad, O'Shea, 2004). As such, the giant squid's diet is consistent with that of both an active predator and that of an ambush predator. A very welcome answer comes in the form of an exceptional report by Kubodera and Mori (2005): unprecedented film footage of a live Architeuthis in its natural habitat, 900m deep in the North Pacific. These authors attained this feat after many decades of frustrated efforts by tens of other researchers. The film shows many images of the squid grabbing bait, showing that it is indeed a fast and powerful swimmer, capturing its prey with its long, strong tentacles. Nevertheless, in order to end the debate once and for all, the only thing remaining is to see a live Architeuthis capturing live, active prey. 
The vertical distribution of Architeuthis, i.e. the depths at which it lives, is also somewhat uncertain. At first, it was thought that these animals inhabited abyssal depths (Steenstrup, 1857), but more recent evidence points to another pattern. The vertical distribution of the predators of Architeuthis can be used to infer where the giant squid lives. Juvenile giant squids are preyed upon by sharks and bony fishes (Roper, Young, 1972; Cherel, 2003), while adults are preyed upon almost exclusively by sperm whales (Roper, Boss, 1982; Clarke, 1980; Aldrich, 1991). Therefore, it is claimed that the giant squid lives between the surface and 1,100m deep (possibly reaching 2,000m; Roper, Boss, 1982). However, there is evidence that there could be differences: (1) in the depths inhabited by different populations (or species) around the globe (Roeleveld, Lipinski, 1991); (2) among age classes, with juvenile squids living closer to the surface and adults inhabiting greater depths (Roper, Boss, 1982; Lu, 1986; Robison, 1989; Förch, 1998); (3) for the same animal, which could vertically migrate daily, living closer

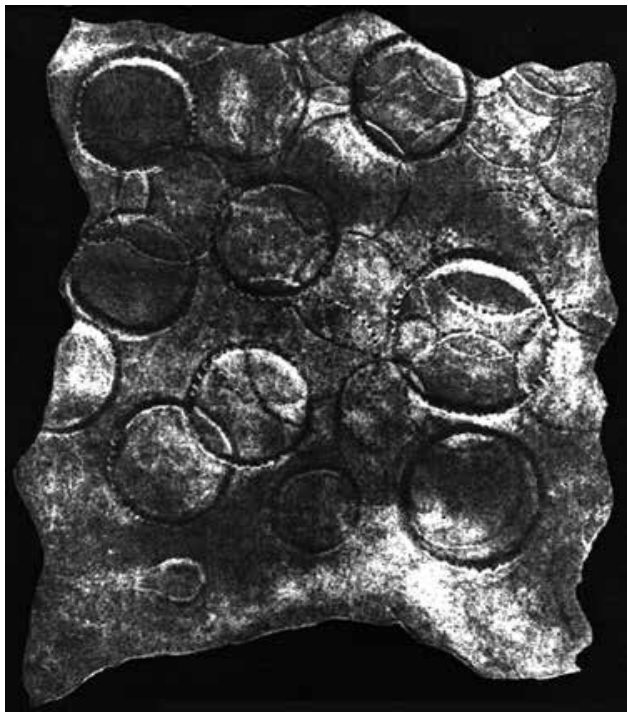

Figure 12: A patch of skin of a sperm whale showing the scars left by a giant squid's suckers (J. Murray and J. Hjort [1921]. Available at: http://commons. wikimedia.org) to the surface during the day but deeper during the night (Roeleveld, Lipinski, 1991).

Sperm whales are the great predators of adult Architeuthis (Roper, Boss, 1982; Aldrich, 1991) and the battles between these titans are perhaps more frequent than once imagined. It is very common to find scars on whales' skin (Figure 12) left by giant squids' suction cups, whose edges are armed with small but sharp chitinous denticles (Roper, Boss, 1982). Both the arms and the tentacle's clubs have suction cups, but the scars are probably caused by the squids' arms (Ellis, 2004), even if the reconstruction of such battles show the tentacles wrapped tight around the whale (Figure 13). Architeuthis tentacles can reach more than $10 \mathrm{~m}$ in length, but it is impossible for the animal to use them as constricting weapons, for they lack the musculature for this (Roper, Boss, 1982; Ellis, 2004). A giant squid could never overcome a sperm whale in a duel (actually a preying attempt by the latter) and its only option would be to quickly escape (Aldrich, 1991). Surprisingly, Aldrich (1991) reports similar scars to those found on sperm whales in specimens of Architeuthis, meaning that some sort of confrontation may occur between conspecifics. Unfortunately, it is not possible to tell if such disputes are related to feeding, reproduction or even to some other unanticipated reason. This piece of information could also be related to the reports of supposed cannibalism (Bolstad, O'Shea, 2004), in which pieces of tentacles and arms of Architeuthis were found in the stomach contents of conspecifics. Curiously, Architeuthis, as well as many other cephalopods, seems to be able to regenerate lost portions of its tentacles (Aldrich, Aldrich, 1968).

Data about Architeuthis reproduction are also scarce. The giant squid seems to show great sexual dimorphism in size, with females growing much larger than males; however, the 


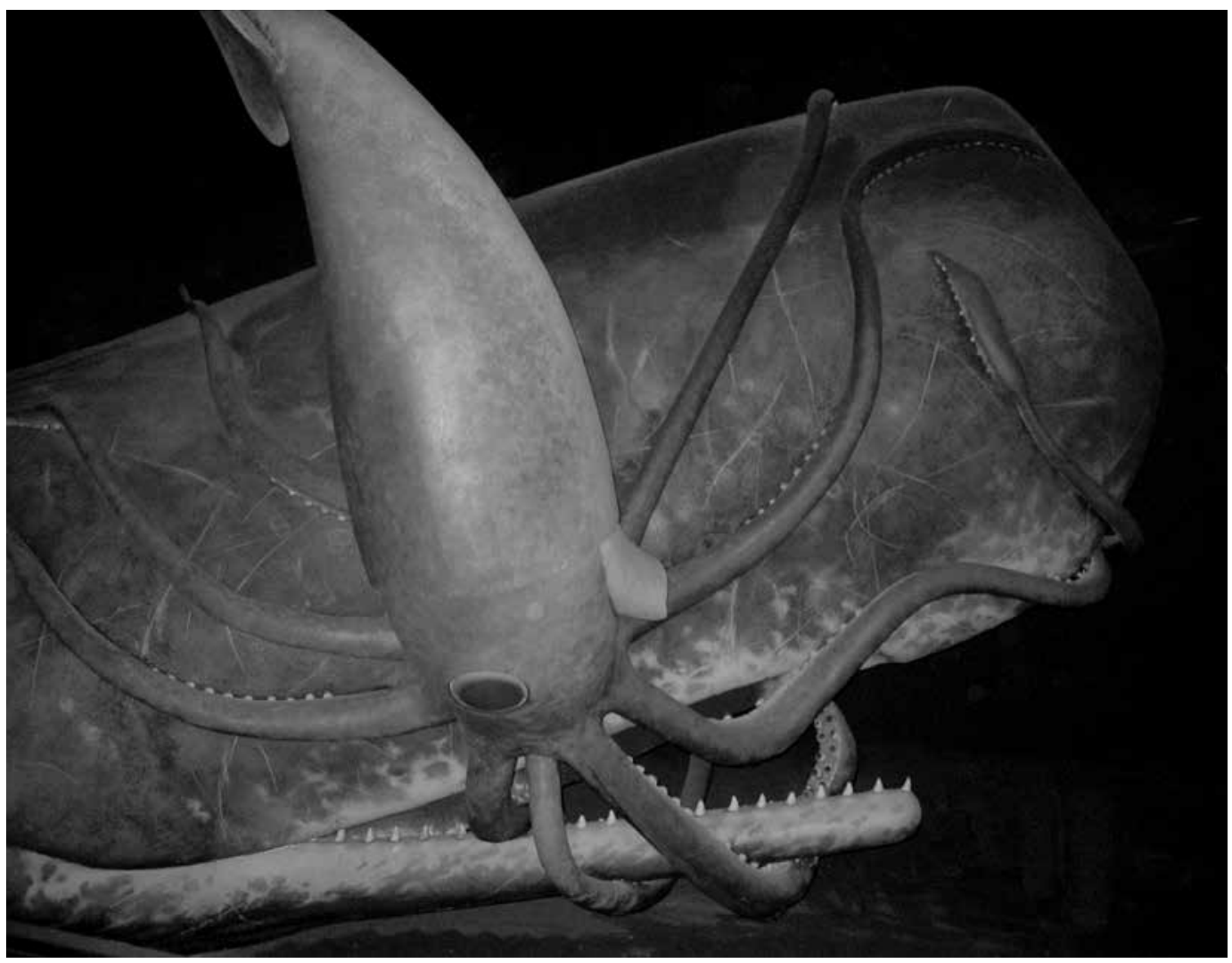

Figure 13: Reconstruction of an epic battle between a giant squid and its nemesis, the sperm whale, in exhibition at the American Museum of Natural History, New York, USA (American Museum of Natural History. Available at: http:// commons.wikimedia.org

implications of this fact remain unknown (Hoving et al., 2004). Reproduction in cephalopods occurs with the transfer of spermatophores, small structures containing the sperm (Rocha, Guerra, González, 2001). Generally, one of the male's arms bears special modifications to perform the spermatophores' transference and is called a hectocotylus (Rocha, Guerra, González, 2001). This structure is also present in Architeuthis (Knudsen, 1957; Roper, Boss, 1982; Aldrich, 1991), but spermatophore transfer seems to be a little unusual: spermatophores have been found lodged inside the arms of some females (Norman, Lu, 1997; Guerra et al., 2004; Hoving et al., 2004). Few other squids, of much smaller sizes than Architeuthis, show this behavior (Norman, Lu, 1997). In other cephalopods, the spermatophores are usually lodged in an exclusive receptacle inside the female's mantle. Moreover, a female Architeuthis can apparently store spermatophores even when it is not yet sexually mature, which is perhaps a reproductive strategy, since an encounter between two giant squids might not be a very frequent occurrence in the ocean's dark depths (Norman, Lu, 1997; Hoving et al., 2004). The ovaries found in some specimens have led to the estimate that Architeuthis can produce from one million to ten million eggs, each about $1.5 \mathrm{~mm}$ in diameter, and it probably lays them in large gelatinous masses, like some other large oceanic squids (Roper, Boss, 1982; Boyle, 1986; Roeleveld, Lipinski, 1991; Hoving et al., 2004). 
Some young specimens, a few centimeters in length, have been found throughout the world (Roper, Young, 1972; Lu, 1986). Considering the disparity in size between juveniles and adults and the fact that Architeuthis has a life cycle of about two to two and a half years, as is the rule in cephalopods (Rocha, Guerra, González, 2001), it is estimated that its growth rate is incredibly fast (Jackson, Lu, Dunning, 1991; Gauldie, West, Förch, 1994). Little else is known about the giant squid's biology and it is believed that the rest of its physiological and behavioral features are similar to other squids.

\section{Mesonychoteuthis: a new monster?}

The largest Architeuthis ever recorded reaches $18 \mathrm{~m}$ in length (some say $20 \mathrm{~m}$, but the tentacles extend after death, possibly leading to overestimated measures; Ellis, 2004), including the tentacles, and the mantle alone can reach up to $6 \mathrm{~m}$ (Roper, Boss, 1982). However, the vast majority of specimens are much smaller (Clarke, 1966; Roper, Sweeney, Nauen, 1984; Roeleveld, Lipinski, 1991; Norman, 2000). The estimated weight of the largest specimens ranges from 400kg to 1t (Clarke, 1966; Roeleveld, Lipinski, 1991).

But even with such a great size, there is another species of squid that apparently wants to take the place of Architeuthis as the world's largest invertebrate. The "colossal squid" (Mesonychoteuthis hamiltoni, family Cranchiidae), from the Antarctic Ocean, can apparently surpass Architeuthis in both length (by at least 1m) and weight (O'Shea, Bolstad, 2008). However, since not one single gigantic specimen has been recovered (the published accounts record only a maximum of $3 \mathrm{~m}$ mantle length, $10 \mathrm{~m}$ of total length and $\sim 500 \mathrm{~kg}$; Roper, Jereb, 2010), this is simply an estimate made by extrapolation from young specimens or beaks. Moreover, such records have never been published in scientific journals; they are restricted to amateur websites and therefore cannot be confirmed. Thus, despite the greater amount of attention the media has given to Mesonychoteuthis, Architeuthis remains the sea monster par excellence.

\section{Reviving the myth}

Ellis (2004) has managed to gather a large amount of information about sea monsters and their zoological counterparts. In his research, he encountered many people who actually believed that the giant squid was only a myth and were really surprised to discover a real animal behind the legends. It seems the Kraken is still very much alive in folklore, even after so many centuries and so much research. The monster has gained a new lease of life since the 1940s due to its sporadic appearance in pop culture: in movies (e.g. Pirates of the Caribbean: dead man's chest, 2006), fictional literature (e.g. Kraken, by China Miéville, 2010), videogames (e.g. Age of mythology, 2002, and Assassin's creed III, 2012), comic books (mainly in some stories by DC Comics and Marvel Comics) and even music (in the song "Architeuthis", the heavy metal band Tourniquet appropriately defines the animal as the last living mystery).

The first memorable movie starring the Architeuthis was Reap the wild wind (1942), which, as stated by Ellis (2004), defined what the public would come to expect of the giant squid: a monster lurking in sunken ships waiting for reckless divers. Another striking appearance 
of the Kraken is in Walt Disney Studio's adaptation of Twenty thousand leagues under the sea (1954). An interesting case is the movie Clash of the Titans, both the original version (1981) and its recent remake (2010), where the error mentioned earlier can be seen. In this movie, the Kraken appears as a gigantic humanoid monster, taking the place of Cetus in the Greek legend of Princess Andromeda, and therefore inserted in a mythology that has absolutely nothing to do with it.

The most outstanding appearance of the giant squid in the fictional literature is Beast (1991), a novel by Peter Benchley, author of Jaws. As is usual in such stories, the monster goes about killing everyone for no reason whatsoever until it is finally killed in the end. The way Benchley shows the giant squid, as a merciless and vengeful killing machine, drew the attention of Arthur C. Clarke, a renowned science fiction author and great admirer of Architeuthis (the animal had already been featured in many of his short stories). Clarke, as well as many other writers and scientists, believed Benchley's novel Jaws and its movie adaptation were responsible for the ruthless hunting and killing of white sharks which took place shortly after the movie was released; as such, they feared that the same could happen with Architeuthis after Beast (Clarke, 1992). Fortunately, that never happened, certainly because the giant squid is extremely hard to find (and unpalatable due to the ammonium in its muscles) and not because people had suddenly developed greater environmental awareness. For now, the giant squid apparently is not in danger. However, as technology advances, it is possible that these animals will be more easily caught; therefore, maybe in the near future, Architeuthis will need protection or it will definitely become a myth. Architeuthis is an emblematic animal and may even be used as a symbol for environmental protection (Guerra et al., 2011).

\section{Final considerations}

Malacologists have gone a long way in bringing the Kraken to the light of science. Since the first certified record of Architeuthis in 1639 (Steenstrup, 1849), about five hundred other records have been gathered from every region of the globe (Sweeney, 2001; Ellis, 2004). Even with so many records, little is definitely known about the biology of this wonderful animal (Roper, Shea, 2013); not even the taxonomy of the family Architeuthidae is resolved. The giant squid is perhaps the most elusive large animal in the world and this has greatly contributed to the aura of mystery that envelops it. It can be said that even today this animal possesses a semi-mythological status. Despite much scientific research, the myth stills surfaces here and there as the sea monster lurking in folklore and immortalized by art.

\section{REFERENCES}

ALDRICH, Frederick A.

Some aspects of the systematics and biology of squid of the genus Architeuthis based on a study of specimens from Newfoundland waters. Bulletin of Marine Science, v.49, n.1-2, p.457-481. 1991.

ALDRICH, Frederick A.; ALDRICH, Margueritte M. On regeneration of the tentacular arm of the giant squid Architeuthis dux Steenstrup
(Decapoda, Architeuthidae). Canadian Journal of Zoology, v.46, n.5, p.845-847. 1968.

ASHTON, John.

Curious creatures in zoology. London: John C. Nimmo. 1890.

BOLSTAD, Kat S.; O'SHEA, Steve.

Gut contents of a giant squid Architeuthis dux 
(Cephalopoda: Oegopsida) from New Zealand waters. New Zealand Journal of Zoology, v.31, p.15-21. 2004.

BOYLE, Peter R.

Report on a specimens of Architeuthis stranded near Aberdeen, Scotland. Journal of Molluscan Studies, v.52, p.81-82. 1986.

BRIX, Ole.

Giant squid may die when exposed to warm water currents. Nature, v.303, p.422-423. 1983.

CHEREL, Yves.

New records of the giant squid Architeuthis dux in the Southern Indian Ocean. Journal of the Marine Biological Association of the United Kingdom, v.83, n.6, p.1295-1296. 2003.

CLARKE, Arthur C.

Squid! A noble creature defended. Omni, v.14, n.4, p.70-72. 1992.

CLARKE, Malcom R.

Cephalopoda in the diet of sperm whales of the southern hemisphere and their bearing on sperm whale biology. Discovery Reports, v.37, p.1-324. 1980.

CLARKE, Malcom R.

The distribution of giant squids (Cephalopoda, Architeuthidae) in the North Atlantic and particularly about the shores of newfoundland. Sarsia, v.34, n.1, p. 393-398. 1968.

CLARKE, Malcom R.

A review of the systematics and ecology of oceanic squids. Advances in Marine Biology, v.4, p.91-300. 1966.

CLARKE, Malcom R.; DENTON, Erik J.; GILPINBROWN, John B.

On the use of ammonium for buoyancy in squids. Journal of the Marine Biological Association of the United Kingdom, v.59, p.259-276. 1979.

ELLIS, Richard.

Monsters of the sea. Guilford: Lyons Press. 2004.

ELLIS, Richard.

The search for the giant squid: the biology and mythology of the world's most elusive sea creature. Guilford: Lyons Press. 1998.

FÖRCH, Ellen C.

The marine fauna of New Zealand: Cephalopoda: Oegopsida: Architeuthidae (giant squid). NIWA Biodiversity Memoir, v.110, p.1-113. 1998.

GAULDIE, Robert W.; WEST, I.F.; FÖRCH, Ellen C. Statocyst, statolith, and age estimation of the giant squid. Architeuthis kirki. The Veliger, v.37, n.1, p.93-109. 1994.

GESNER, Conrad.

Historiae animalium. Zurich. 1587.
González, María et al.

First record of the giant squid Architeuthis sp. (Architeuthidae) in the Mediterranean Sea. Journal of the Marine Biological Association of the United Kingdom, v.80, p.745-746. 2000.

GRØNNINGSÆTER, Arne.

Sjørmen-blekkspruten. Naturen, v.70, p.379-380. 1946.

GUERRA, Ángel et al.

The giant squid Architeuthis: an emblematic invertebrate that can represent concern for the conservation of marine biodiversity. Biological Conservation, v.144, n.7, p.1989-1997. 2011.

GUERRA, Ángel et al.

Records of giant squid in the north-eastern Atlantic, and two records of male Architeuthis sp. off theIberian Peninsula. Journal of the Marine Biological Association of the United Kingdom, v.84, n.2, p.427-431. 2004.

HAMILTON, Robert.

The Kraken. In: Jardine, William. The naturalist's library: Mammalia, v.3. Amphibious Carnivora, including the walrus and seals, also of the herbivorous Cetacea, \&c. Edinburgh: W.H. Lizars. p.327-336. 1839.

HOVING, Hendrik J.T. et al.

Reproductive system of the giant squid Architeuthis in South African waters. Journal of Zoology, v.264, n.2, p.153-169. 2004.

JACKSON, George D.; LU, Chung-Cheng; DUNNING, Malcolm.

Growth rings within the statolith microstructure of the giant squid Architeuthis. The Veliger, v.34, n.4, p.331-334. 1991.

KNUDSEN, Jorgen.

Some observations on a minute male specimen of Architeuthis from Danish waters. Proceedings of the Malacological Society of London, v.32, n.4, p.189-198. 1957.

KUBODERA, Tsunemi; MORI, Kyioichi. First-ever observations of a live giant squid in the wild. Proceedings of the Royal Society B, v.272, n.1581, p.2583-2586. 2005.

LEE, Henry.

Sea monsters unmasked. London: William Clowes and Sons. 1883.

LINNAEUS, Carl.

Fauna Svecica. Sistens Animalia Svecicæ Regni: Qvadrupedia, Aves, Amphibia, Pisces, Insecta, Vermes, Distributa per Classes \& Ordines, Genera \& Species. Cum Differentiis Specierum, Synonymis Autorum, Nominibus Incolarum, Locis Habitationum, Descriptionibus Insectorum. Stockholm. 1746. 
LINNAEUS, Carl.

Systema Naturae. Sistens Regna Tria Natura in Classes et Ordines, Genera et Species redacta, Tabulisque Æneis Illustrata. Editio multo auctior \& emendatior. Leiden. 1735.

LORDAN, Colm; COLLINS, Martin A.; PERALESRAYA, Catalina.

Observations on morphology, age and diet of three Architeuthis caught off the west coast of Ireland in 1995. Journal of the Marine Biological Association, v.78, n.3, p.903-917. 1998.

LU, Chung-Cheng.

Smallest of the largest - first record of giant squid larval specimen. Australasian Shell News, v.53, p.9. 1986.

MAGNUS, Olaus.

Historia de Gentibus Septentrionalibus. Rome. 1555.

MATTHEWS, John; MATTHEWS, Caitlin.

The element encyclopedia of magical creatures.

London: Harper Element. 2005.

NESIS, Kir N.

Abridged key to the cephalopod mollusks of the world's ocean. In: Nesis, Kir N.; Burgess, Lourdes A. Cephalopods of the world: squids, cuttlefishes, octopuses, and allies. Neptune City: T.F.H. 1987.

NESIS, Kir N. et al.

Records of giant squids of the genus Architeuthis in the North Pacific and South Atlantic.

Zoologicheskiy Zhurnal, v.64, n.4, p.518-528. 1985.

NORDHOFF, Charles.

Whaling and fishing. Cincinnati: Moore,

Wilstach, Keys \& Co. 1856.

NORMAN, Mark D.

Cephalopods, a world guide. Denmark:

ConchBooks. 2000.

NORMAN, Mark D.; LU, Chung-Cheng.

Sex in giant squid. Nature, v.389, p.683-684. 1997.

O’DOR, Richard K.

The energetic limits on squid distributions. Malacologia, v.29, n.1, p.113-119. 1988.

OGDEN, Robert $S$. et al.

The role of beak shape in octopodid taxonomy. South African Journal of Marine Science, v.20, n.1, p.29-36. 1998.

O'SHEA, Steve; BOLSTAD, Kat S.

Giant squid and colossal squid fact sheet. The octopus news magazine online. Available at: http:// www.tonmo.com/science/public/giantsquidfacts. php. Access on: 29 Sep., 2012. 2008.
PÉREZ-GÁNDARAS, Germán; GUERRA, Ángel. Architeuthis de Sudáfrica: nuevas citas y consideraciones biológicas. Scientia Marina, v.53, n.1, p.113-116. 1989.

PÉREZ-GÁNDARAS, Germán; GUERRA, Ángel. Nueva cita de Architeuthis (Cephalopoda: Teuthoidea): descripcion y alimentacion. Investigación Pesquera, v.42, n.2, p.401-414. 1978.

PONTOPPIDAN, Erik.

Versuch einer natürlichen Geschichte Norwegens. Copenhagen. 1752-1753.

PONTOPPIDAN, Erik.

Det Forste Forsorg paa Norges Naturlige Historie. Copenhagen: Berlingste Arvingers Bogtrykkerie. 1752.

ROBISON, Bruce H.

Depth of occurrence and partial chemical composition of a giant squid, Architeuthis, off Southern California. The Veliger, v.32, n.1, p.39-42. 1989.

ROBSON, Guy C.

On Architeuthis clarkei, a new species of giant squid, with observations on the genus. Journal of Zoology, v.103, n.3, p.681-697. 1933.

ROCHA, Francisco; GUERRA, Ángel; GONZÁLEZ, Ángel $\mathrm{F}$.

A review of reproductive strategies in cephalopods. Biological Reviews, v.76, n.3, p.291304. 2001.

ROELEVELD, Martina A.C.

Giant squid beaks: implications for systematics. Journal of the Marine Biological Association of the United Kingdom, v.80, n.1, p.185-187. 2000.

ROELEVELD, Martina A.C.; LIPINSKI, Marek R. The giant squid Architeuthis in southern African waters. Journal of Zoology, v.224, n.3, p.431-477. 1991.

ROPER, Clyde F.E.; BOSS, Kenneth J.

The giant squid. Scientific American, v.246, n.4, p.96-105. 1982.

ROPER, Clyde F.E.; JEREB, Patrizia.

Family Crachiidae. In: Jereb, Patrizia; Roper, Clyde F.E. Cephalopods of the world. An annotated and illustrated catalogue of species known to date. v.2. Myopsid and Oegopsid Squids. FAO species catalogue for fishery purposes, v.2, n.4, p.241-246. Rome: FAO. 2010.

ROPER, Clyde F.E.; SHEA, Elizabeth K. Unanswered questions about the giant squid Architeuthis (Architeuthidae) illustrate our incomplete knowledge of coleoid cephalopods. American Malacological Bulletin, v.31, n.1, p.109-122. 2013. 
ROPER, Clyde F.E.; SWEENEY, Michael J.; NAUEN, Cornelia E.

FAO species catalogue v.3, Cephalopods of the world: an annotated and illustrated catalogue of species of interest to fisheries. FAO Fisheries Synopsis, v.125, n.3, p.1-277. 1984.

ROPER, Clyde F.E.; YOUNG, Richard E. First records of juvenile giant squid, Architeuthis (Cephalopoda: Oegopsida). Proceedings of the Biological Society of Washington, v.85, n.16, p.205222. 1972.

ROSA, Rui; PEREIRA, João; NUNES, Maria L. Biochemical composition of cephalopods with different life strategies, with special reference to a giant squid. Architeuthis sp. Marine Biology, v.146, n.4, p.739-751. 2005.

SEIBEL, Brad A.; THUESEN, Erik V.; CHILDRESS, James J.

Light-limitation on predator-prey interactions: consequences for metabolism and locomotion of deep-sea cephalopods. Biological Bulletin, v.198, n.2, p.284-298. 2000.

STEENSTRUP, Japetus.

Oplysninger om Atlanterhavets colossale Blaeksprutter. Førhandlingar ved de Skandinaviske Naturforskeres, n.7, p.182-185. 1857.

STEENSTRUP, Japetus.

Meddelese om tvende kiaempestore Blaeksprutter opdrevne 1693 og 1790 ved Islands Kyst, og om nogle andre nordiske Dyr. Førhandlingar ved de Skandinaviske Naturforskeres, n.5, p.950-957. 1849.

SWEENEY, Michael J.

Records of Architeuthis specimens from published reports. Available at: www.mnh.si.edu/cephs/ archirec.pdf. Access on: 29 Sep. 2012. 2001.

TENNYSON, Alfred Lord.

Poems, chiefly lyrical. Philadelphia: University of Pennsylvania Press. 1830.

THOMSON, Alastair W.

The poetry of Tennyson. London: Routledge Kegan \& Paul. 1986.
TOLL, Ronald B.; HESS, Steven. C.

A small, mature male Architeuthis (Cephalopoda: Oegopsida) with remarks on maturation in the family. Proceedings of the Biological Society of Washington, v.94, n.3, p.753-760. 1981.

TRYON, George W.

Manual of conchology: v.1, Cephalopoda.

Philadelphia. 1879.

VERNE, Jules.

Twenty Thousand Leagues Under the Sea. Oxford: Oxford University Press. 1870.

VERRILL, Addison E.

The cephalopods of the north-eastern coast of America. Part I. The gigantic squids (Architeuthis) and their allies; with observations on similar large species from foreign localities. Transactions of the Connecticut Academy of Sciences, v.5, n.23, p.177-257. 1879-1880.

VERRILL, Addison E.

The colossal cephalopods of the North Atlantic. American Naturalist, v.9, n.1, p.21-36. 1875.

VERRILL, Addison E.

The giant cuttle-fishes of Newfoundland and the common squids of the New England coast. American Naturalist, v.8, n.3, p.167-174. 1874.

VOIGHT, Janet R.; PÖRTNER, Hans O.; O'DOR, Ronald $\mathrm{K}$.

A review of ammonia-mediated buoyancy in squids (Cephalopda: Teuthoidea). Marine and Freshwater Behavior and Physiology, v.25, p.193-203. 1994.

WALLENBERG, Jacob.

Min son på galejan, eller en ostindisk resa innehållande allehanda bläckhornskram, samlade på skeppet Finland, som afseglade ifrån Götheborg $i$ Dec. 1769, och återkom dersammastädes $i$ Junii 1771. Stockholm: Elméns och Granbergs Tryckeri. 1835.

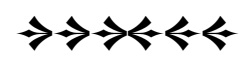

